For citation: Ramos, D., Madeira, M. J. \& Duarte, F. A. P. (2020). Entepreneurship Education and Entrepreneurial Intention: the Case of Portugal. Ekonomika regiona [Economy of region], 16(1), 157-170

https://doi.org/10.17059/2020-1-12

UDC: 330.3

\author{
D. Ramos $^{a)}$, M. J. Madeira ${ }^{a, b)}$, F. A. P. Duarte ${ }^{a, b, c)}$ \\ a) University of Beira Interior (Covilhã, Portugal) \\ b) NECE - Research Centre in Business Sciences (Covilhã, Portugal; e-mail: maria.jose.madeira@ubi.pt) \\ c) Polytechnic Institute of Viseu (Viseu, Portugal)
}

\title{
ENTEPRENEURSHIP EDUCATION AND ENTREPRENEURIAL INTENTION: THE CASE OF PORTUGAL ${ }^{1}$
}

\begin{abstract}
Entrepreneurship promotes job creation, increase of competitiveness and new forms of economic development and growth of countries or regions. The research aims to understand how it has influenced the intention and entrepreneurial skills of the trainees of the project Apreender 3.0. It is important to examine how various factors, including entrepreneurship education, family background, prior experience/vocational training and propensity to take the risks, will condition the entrepreneurial intention of the respondents of this study. Based on these variables, we formulated four hypotheses. For this empirical analysis of research hypotheses, we used primary data in a form of a sample of 150 responses, collected through the online survey application. We opted for the method of the Exploratory Factor Analysis (EFA), also called Common Factor Analysis (CFA), which can provide important information on the multivariate structure of this study, identifying the theoretical constructs. The obtained results allowed us to conclude that the entrepreneurship education and propensity to take risks influence positively the entrepreneurial intention. As for the factors of family background and prior experience/vocational training, the research did not provide satisfactory results that would allow us to confirm their influence on the entrepreneurial intention.
\end{abstract}

Keywords: entrepreneurship, entrepreneur, entrepreneurial intention, education, family background, prior experience, vocational training and risks propensity

\section{Introdution}

In the current global context, the existence of a movement that promotes and reinforces entrepreneurship education is a reality [1-5]. The concept of entrepreneurship includes the reference to specific attitude and the ability to respond to the surrounding environment, in the sense of searching for the solutions that add value to society.

As defined by the European Commission, entrepreneurship is «the ability of an individual to turn ideas into action» [6]. It is an exercise, which combines creativity, innovation and the ability to take calculated risks, plan and manage projects as to achieve certain objectives. Hence, entrepreneurship is regarded as a key factor for ensuring the dynamism of a market economy, as well as for obtaining a higher rate of development of new businesses [7-11]. Entrepreneurship education comprises the activities that involve the development of knowledge, approaches, attitudes and assets $[12,13]$. During the education process, the focus should be on a set of skills that must be passed on according to the age and development of the student in question.

\footnotetext{
${ }^{1}$ (C) Ramos D., Madeira M. J., Duarte F. A. P. Text. 2020.
}

In this research, we focused on studying the entrepreneurial intention of the trainees of the project Apreender 3.0 of the central region, as well as on how it is influenced by determinant factors, such as the teaching of entrepreneurship, previous professional experience, family background and risk propensity. The study is divided in 5 sections. In the first section, we present a brief introduction, describing the chosen theme and the research objective. In the second section, we reviewed the literature and established the main concepts contributing to the understanding of the study: (1) Entrepreneurial intention, (2) Entrepreneurship Education, (3) Previous work experience/training, (4) Family Background and (5) Risk Propensity. In the end of this section a model of analysis and a scheme proposing the conceptual model are introduced. The third section is dedicated to the Research Methodology, while the fourth section regards data analysis and the discussion of results. In the final section, we present the main conclusions and future research lines, taking into account the current study.

\section{Literature Review}

This research aims to assess the entrepreneurial intention of the trainees of the project 
Apreender 3.0 of the central region by analysing a few determinant factors. The concept of entrepreneurial intention has been used to comprise a number of other related concepts such as career guidance [14], professional aspirations [15], firsttime entrepreneurs [16], self-employment perspective [17] and the desire to start one's own business [18]. Therefore, it is relevant to study this topic. Thus, following a theoretical approach, in this chapter we will examine all the determinants of entrepreneurial intention regarded in the study.

\subsection{Entrepreneurial intention}

Entrepreneurial intentions are a key element in the performance of entrepreneurship activities, corresponding to an important indicator of such activities [12]. Entrepreneurial intention is considered as the first step in the process of discovery and exploration of opportunities [19]. Thus, the intention is a fundamental element for understanding of entrepreneurship [20].

With regard to the literature on entrepreneurial intention, one can verify that there is no entrepreneurial behaviour without entrepreneurial intention. In fact, there are various points of view and perspectives defended by different authors. It is possible to find several research articles that identify two theoretical models related to the topic of entrepreneurial intentions, namely: (I) Shapero's conceptual Model (1982) [21]: Model of Entrepreneurial intention and (II) Ajzen's conceptual Model (1991): Theory of Planned Behaviour. Ajzen (1991) [22] claimed that any behaviour always requires proper planning before being executed, meaning that the process of creating a particular business may be determined in advance by the intention of an individual. Therefore, through the Theory of Planned Behaviour, it is possible to identify if a certain individual intends to create a new business project by assessing his entrepreneurial intention.

Liñán [12] states that intention becomes the essential and driving force of an individual's behaviour once it displays a person's effort to accomplish entrepreneurial behaviour. Previous studies have found that the entrepreneurial intention is determined by a variety of cognitive and contextual factors that may positively or negatively influence entrepreneurial intention, often modelling it in combinations or as interactions [23]. According to Brandstatter [24] and Ip [25], earlier studies have suggested that personality traits are relevant in entrepreneurship and entrepreneurial intention. One may say that a person with well-developed IE is more likely to perform factors that determine entrepreneurial intention [26].
Thus, the entrepreneurial intention is related to the will and commitment of an individual to create a business [27]. This intention is defined as an action to achieve a certain goal, meaning that the greater is the intention to effect a behaviour, the greater are the probabilities of its effective performance [28].

\subsection{Entrepreneurship Education}

According to the behaviourist approach, education can contribute to an increasing entrepreneurship ability [22, 29]. The intended change in behaviour, aimed at making population groups more accessible to entrepreneurship, results in putting into practice current Entrepreneurship Education (EE) through formal and informal educational processes. However, the more an individual learns about entrepreneurship, the more they become aware of the existence of this option as a professional activity [12]. Nonetheless, [30] states that entrepreneurship is a set of steps that can be learned and, therefore, can be taught. Along the same lines, [13] claim to be in favour of entrepreneurship education. These authors defend the idea that students who specialize in entrepreneurship should get a detailed education about different ways of managing a start-up from a variety of perspectives, including business, law, macroeconomics, and public policy. Literature suggests that entrepreneurship positively impacts economic development through job creation and inclusive growth [31]. Portuguese universities should integrate entrepreneurship in their educational programs and stimulate the participation of their students in courses or subjects of entrepreneurship, paying special attention to the engineering and scientific areas, in order to create a corporate culture that will eventually result in the creation of spin-offs [9].

Thus, it is important to realize how Entrepreneurship Education will condition the entrepreneurial intention of the respondents in this study. After reviewing the academic literature on Entrepreneurship Education, we state the first hypothesis of this study. H1: Entrepreneurship Education positively influences the Entrepreneurial Intention (EI) of the Project Apreender 3.0 trainees.

\subsection{Family Background}

There are several factors associated with personal background that may be related to an individual's entrepreneurial intention. One of these factors is the family background and the way it influences the entrepreneurial intention. Research on the subject has demonstrated that 
the presence in the family of people who own businesses, in particular, the activity performed by one's father and mother, is considered a key factor in the choice to create one's own business [32]. According to these authors, individuals with family members involved in entrepreneurial activities were more prominent in their performance, distinguishing themselves from individuals without this background. Also, several studies on entrepreneurship report that the family factor is determinant for this phenomenon, due to the background provided to the individual [33, 34], or to an entrepreneurial model in the family [35].

One of the important aspects of stimulating entrepreneurial behaviour and encouraging the creation of business is precisely related to the family core, that is, the experience of relatives acting as models and references [21]. However, some authors do not believe that the behaviour and opinion of one's family directly influence children's entrepreneurial intentions. The fact that the parents are entrepreneurs does not mean that their children will be entrepreneurs as well. In studies [36] and [37] the authors analysed the levels of entrepreneurial intention, as well as some influencing factors, namely, the family background. The authors surveyed 2010 students from nine universities in China, having concluded that family background has no significant impact on the students' entrepreneurial intention.

Researchers [17], [38] and [39] claim that individuals who are part of an entrepreneurial family, that is, have a family business, have greater entrepreneurial intentions, increasing the perception that self-employment is a career option and that it is possible to obtain higher incomes. Thus, entrepreneurial intention can be influenced by genetic factors [39]. However, these authors state that, in practice, many entrepreneurs do not have this family «background», that is, they do not have a family business. Social engagement also influences an individual's entrepreneurial decisions. The study GEM [40] notes that people who have difficulties finding a job or are socially distanced often seek a solution for that situation through creating a company or business.

Considering what has been stated above and despite the lack of consensus regarding the family influence on the entrepreneurial intention, it is possible to assess that the family history can or cannot influence the entrepreneurial intention. Thus, we have formulated the following hypothesis of investigation. H2: Family background positively influences the entrepreneurial intention of the trainees in the project Apreender 3.0.

\subsection{Prior Professional Experience/Training}

The study of the factors that influence entrepreneurial intention is relevant, especially given the socioeconomic benefits generally attributed to entrepreneurship [41]. Thus, in this study, it is important to highlight the prior professional experience and/or training of the entrepreneurs. Entrepreneurship guidance has been used as a driving force to improve entrepreneurial skills [42, 43]. Therefore, entrepreneurial experience was regarded as a factor that influences entrepreneurial intention [44]. [45] conducted studies comparing the cross-cultural entrepreneurial intention between Sweden, the United States and Norway. They have identified that past entrepreneurial experience is an important representation of the entrepreneurial intention. The authors also demonstrated that one's professional experience as a worker does not have a significant impact on the entrepreneurial intention, contrary to the results obtained by [46] which established that this variable is decisive for the success of an enterprise. These authors, on the other hand, confirm the results of study [45] by highlighting the importance of living as an entrepreneur to obtain a higher profit.

In their study involving college students, [47] demonstrate that professional experience plays a significant role in the development of entrepreneurial intention. The study [48] considers that even experiences acquired in the educational context (such as summer internships, consulting about projects with start-ups, writing case studies about entrepreneurs, among others) should increase students' intentions to start a business.

To sum up, according to [31] the openness to experience is characterized by curiosity and exploration of new experiences. Both of these qualities are essential for the establishment of new enterprises, as entrepreneurs have to explore new ideas for their products or services.

Considering the studies mentioned above, it is possible to assert that previous professional experience can influence the entrepreneurial intention for someone to start a new business; thus, we formulated the third hypothesis of our research. H3: An individual's prior Professional Experience/ Training positively influences the entrepreneurial intention of the trainees in the project Apreender 3.0.

\subsection{Risk Propensity}

The propensity to take risks is an essential part of entrepreneurship, since an individual does not have, in advance, the assurance that the desired products can be produced, whether consumer 


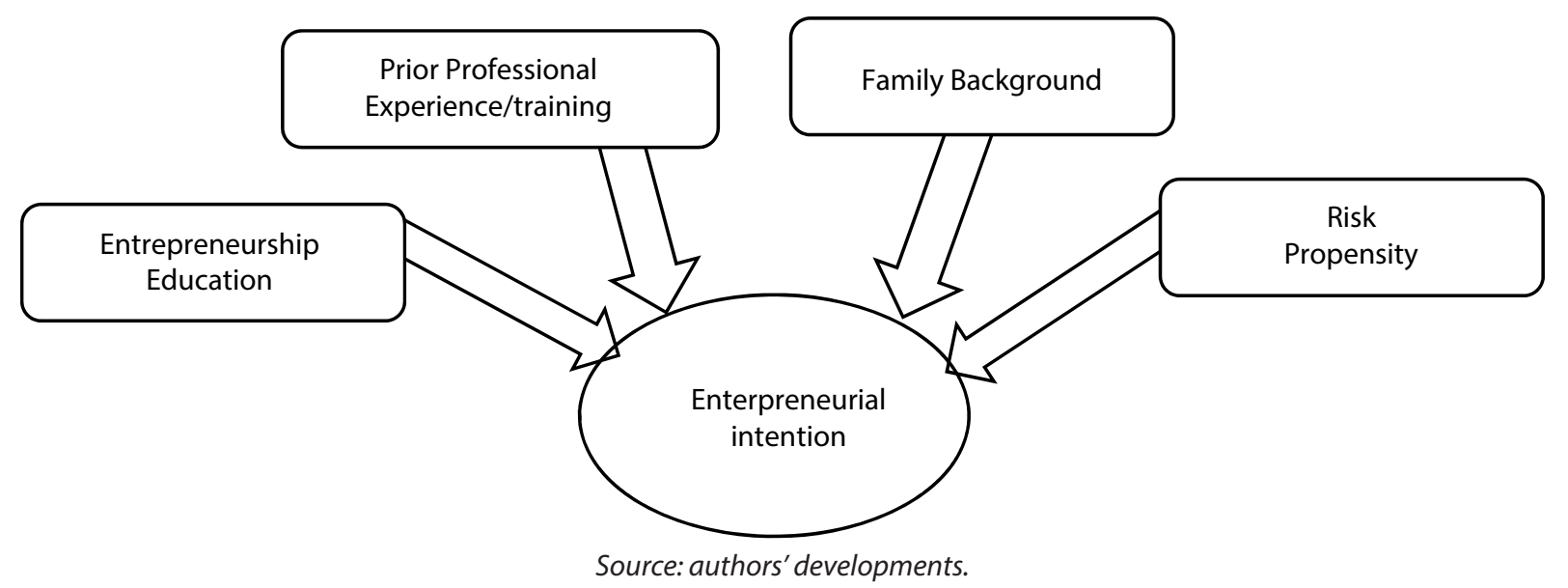

Fig. 1. Analysis model of the research

needs can be met or whether profits can be generated before a new product or service is introduced. Thus, there is always a risk involved. When considering the importance of entrepreneurship, it is necessary to know the conditions of an environment conducive to entrepreneurship and how willing people are to take risks. Besides, it is relevant to examine the relationships of influence in the formation of propensity to risk and their positive contribution to the construction of policies aimed at the strengthening of entrepreneurship [49].

The study [50] points out that some individuals, when perceiving the existence of less risks in certain environments, tend to be more entrepreneurial than others when influenced by a feeling of optimism, besides their own qualification that can also encourage them [49]. Research suggests that entrepreneurs are not necessarily willing to take risks but tend to view situations of risk in a more positive way [51].

The risk that the future entrepreneur is willing to take depends on several variables, be they internal or external to the actions [52]. The study [53] points out that, among several variables, the entrepreneur's sense of power (the feeling that he will achieve everything he wants, when he wants it, with a low level of fear) is a peculiar characteristic even among entrepreneurs who have already failed. Such a positioning can be interpreted in a negative way, which can discourage entrepreneurs.

According to the study [54], successful individuals who previously experienced risk situations are more willing to take risks again, in addition to deciding to voluntarily assume the risk of a venture, not influenced by external factors such as need and present the typical characteristics of an entrepreneur, including creativity and risk attitude.

Thus, the risk propensity associated with undertaking can vary according to the attributes of the entrepreneur and the specific socioeconomic context, which interferes with the entrepreneurial activity of a country or a region. Therefore, with the objective of knowing how the propensity to take risks affects the entrepreneurial intention of the interviewees in this investigation, we formulated the fourth hypothesis. H4: The propensity to take risks positively influences the entrepreneurial intention of the trainees in the project Apreender 3.0.

\subsection{Analysis Model}

After reviewing the literature, it is possible to elaborate the investigation conceptual model, where it is possible to observe how each determinant factor can influence the entrepreneurial intention (Fig. 1).

\section{Methodology}

After the theoretical approach of the topic, we intend to test the hypotheses empirically. We used data collected in a primary form through a survey.

\subsection{Data Collection and Sample}

The research was conducted with a sample of the trainees from the central region of Portugal (Fundão, Covilhã, Castelo Branco, Coimbra, Leiria, Figueira da Foz, Aveiro, Abrantes, Guarda, Viseu, Porto, Lisbon and Santarém) who attended the workshops carried out under the project Apreender 3.0 in 2017/18. For the development of this study we collected the data through a questionnaire that was elaborated drawing on some questions from the Entrepreneurial Intention Questionnaire (EIQ) from authors Liñán and Chen (2009) [12]. The instrument was validated in a cross-cultural research conducted in Spain and Taiwan and is based on Ajzen's TPB (1991) [22]. The EIQ intends to test the model of entrepreneurial intention through its measurement and the variables that work as an influence. The questionnaire was 
addressed to the trainees who attended the workshops carried out under the project Apreender 3.0 in 2017/18, of the central region of Portugal. To collect the data, we used the online platform Google Forms, in the period between January 15th and March 15th of 2018, drawing a total of 150 responses, all of which were submitted to statistical analysis.

\subsection{Variables to be considered}

Next, we present all the variables that make up the object of the study in this assessment, namely, dependent and independent variables: Entrepreneurial Intention, Entrepreneurship Education, Family Background, Prior Professional Experience/Training and Risk Propensity.

\subsubsection{Dependent variable}

In order to meet the research objectives, the «Entrepreneurial Intention» of the trainees in the Project Apreender 3.0 was considered as a dependent variable. In this sense, the constructed research hypotheses are related to the verification of the influence that the independent variables linked to the entrepreneurship exercise on these trainees' viewpoints and entrepreneurial intention. This study means to perceive how the entrepreneurial intention of the trainees involved in the Project Apreender 3.0 is influenced by other variables. Hence, it is crucial to analyse the prospects and intention of these trainees to create their own business. The dependent variable «Entrepreneurial Intention» was assessed using a set of affirmations measured by the Likert scale, with 5 levels of agreement in the answers $(1=$ I totally disagree; 2 = I disagree; $3=$ Neither agree nor disagree; 4 = I agree; 5 = I totally agree).

\subsubsection{Independent Variables}

Next, we establish the independent variables that were part of the questionnaire, which are (1) Entrepreneurship Education, (2) Family Background (3) Prior Professional Experience/ Training and (4) Risk Propensity. The variable «Entrepreneurship Education» will allow us to analyse the trainees who attended the cycle of workshops held within the activities of the project Apreender 3.0. Additionally, it will help to understand if the training works as a motivation to become an entrepreneur, subsequently relating it to entrepreneurial intention. The variable «Entrepreneurship Education» was assessed by two sets of statements corresponding to Likert scale of 5 ordered response levels: (1) «I totally disagree» and (5) «I totally agree»; (1) «Not Important» and (5) «Extremely Important».
The variable «Family Background» allows to examine, whether the students who answered the questionnaire have a close relative (parents, siblings, grandparents, uncles) who are entrepreneurs and if this, in any way, influences their entrepreneurial intention. It was assessed using the question "Is one of your close relatives (parents, siblings, uncles, grandparents) an entrepreneur".

Next, the variable «Prior Professional Experience/Training» allows us to understand if this variable has any positive influence on the entrepreneurial intention of the trainees of the project Apreender 3.0 of the central region.

Lastly, the variable «Risk Propensity» aims to analyse how the trainees of the project Apreender 3.0 face the risks related to the business environment. Moreover, it assesses risk factors connected with choosing a new job, starting a business, as well as the factors that the trainees consider important for the success of a new company. The trainees have to realize, whether they are willing to take risks to create their own job or not, as it greatly influences their entrepreneurial intention.

\subsection{Method}

In this research, we opted for the Exploratory Factor Analysis (EFA), also called Common Factor Analysis (CFA), which can provide important information about the multivariate structure of this study, identifying the theoretical constructs [55]. In order to facilitate the interpretation of the factorial solution, several rotation methods were employed. The Kaiser-Meyer-Olkin criterion (KMO) and the classifications defined by [56], as well as the Bartlett's test of sphericity were used to assess the validity of the EFA, indicating sufficient correlations between the variables to proceed with the EFA [57].

Firstly, we obtained the factorial solution, which explains the correlational behaviour of the variables. Then, we focused on determining the factorial weights and the commonalities of each variable in a given factor, since, in practical terms, the value of $50 \%$ of the total variance is a value that should be regarded as the acceptable minimum [56]. The determination of composed scores $(Z)$ of the scales was accomplished by calculating the number of mean deviations of the variables that compose it, represented by $Z=(x-\mu) / \delta$, where $(x)$ is a value of $(\mu)$ which is the population average and $(\delta)$ is the standard deviation.

For the validation of the research hypotheses we used simple linear regression models, in which the dependent variable corresponded to each of the constructs related to attitudes/intention/entrepreneurial behaviour, while the independent 
variable are those referring to the hypotheses. In a second phase, we used multiple linear regression models, the dependent variables being the attitudes/intention/entrepreneurial behaviour constructs, and the independent variables are those referring to the hypotheses. In the case of multiple linear regressions, the existence of variables with potential effects of multicollinearity through variance inflation factors (VIF) was analysed; these should be inferior to 10 , ideally inferior to 5 [57].

\section{Data Analysis and Discussion of Results}

\subsection{Sample characterization}

The research had a total of 150 responses; the sample was characterized in terms of Gender, Age, Academic Education, Training Area, and Country of origin and the current Municipality of residence. Gender analysis shows an advantage regarding women, as out of the sample of 150 interviewees, $54.7 \%$ are women and $45.3 \%$ are men. Regarding age, we divided the interviewees into 5 five age groups: (1) $18-28$, (2) 29-38, (3) 39-49, (4) 50-61 and (5) over 62. The obtained results show that the age group between $18-28$ has the highest percentage with $36 \%$, followed by the 29-38 group with $21.3 \%$, the 39-49 group with $27.3 \%$, the $50-$ 61 with $14 \%$ and the over 62 group with $1.3 \%$. As for Academic education, half of the sample holds a college degree - Licenciatura (50.7\%), $28.7 \%$ have a Master's degree, $10 \%$ finished high-school, a minority of $6 \%$ has a Doctoral degree, and $4 \%$ of the interviewees have a Bachelor's degree. (TN) Regarding the issue of the area of training, we grouped people in accordance with the National Classification of Education and Training Areas, according to the Ministry of Economic Activities and Labour Ministerial Decree (Portaria 256/2005 of 16 March). According to the classification of the interviewee's training areas, about $43 \%$ of the respondents have academic qualifications in the areas of Social Sciences, Commerce and Law, $20 \%$ in the area of Engineering and Manufacturing Industries, and a smaller percentage of $4 \%$ have qualifications in the area of Educational Sciences. As can be verified, the majority of the surveyed trainees are from the areas of Social Sciences, Commerce and Law. The answers to the question «country» reveal that close to $77 \%$ of the participants come from Portugal, followed by Brazil with $10 \%$, Angola with $4.7 \%$, Cape Verde and France with $2 \%$, Costa Rica with $1.3 \%$ and the remaining countries, Greece, Lebanon, Mozambique and Venezuela with the same percentage of $0.7 \%$. In a similar way, the question «Municipality where you currently reside» allowed us to perceive that more than half of the sample resides in the municipality of Coimbra (52\%), $12 \%$ in the municipality of Lisbon, 8 \% in Covilhã, 6 \% in Aveiro, $5.3 \%$ in Figueira da Foz, 5.3 \% in Castelo Branco, $3.3 \%$ in Viseu, 2.7 \% in Porto, 1.3 \% in Guarda, 1.3 \% in Leiria, $1.3 \%$ in Santarém, $0.7 \%$ in Abrantes and $0.7 \%$ in Vila Real.

\subsection{Data Analysis}

After the characterization of the sample, where some sociodemographic characteristics of the participants of this study were acknowledged, we present the analysis and discussion of the results.

\subsubsection{Entrepreneurial Intention}

We performed the factorial analysis of the Entrepreneurial Intention/Ability with Varimax rotation and either the results of the KMO (0.910) and those of the Bartlett's test $\left(X_{2}(276)=2656.61\right.$; $p<0.001)$ presented good outcomes. Variables 14 , 17,21 and 27 were removed from the statements (I can easily persuade people with my line of reasoning; I often take risks when I believe that something will come out of it, even if I cannot fully predict the consequences of my actions; I can identify some product/service with the potential to be the best in the market; I am always sure of the result that I will get when I make my decisions), respectively, because they presented factor loads below 0.50 .

We observed high values in the commonalities of each variable as displayed in Table 1 , which indicates that the extracted components (latent factors) are a good representation of the variables. The only variables that presented lower values were 1,13 and 28 . The commonalities are the proportions of the variation of each variable that are explained by the latent factor.

In this solution, as can be observed in Table 2, five factors were assessed, which were formed from the performed factor analyses. They are factor 1 (Being an entrepreneur), factor 2 (Creating a company), factor 3 (Entrepreneurial competence), factor 4 (Entrepreneurial difficulties), and factor 5 (Entrepreneurial ability). These factors, with values greater than 1 , represent $72.10 \%$ of the variability in the original variables. This fact suggests that there are 5 latent influences associated with entrepreneurial intention, approximately $27 \%$ remaining unexplained. The analysis of the consistency of the variables, using Cronbach's alpha coefficient and the total scale with all the variables of (1-28), demonstrated a very good internal consistency, demonstrated through (Cronbach's Alpha $=0.930$ ). We analysed the internal consistency of each factor after removing the items with 
Factor Analysis for Entrepreneurial Intention/Ability

\begin{tabular}{|c|c|c|}
\hline & Initial & Extraction \\
\hline 1-Starting a company and keeping it running would be easy for me. & 1,000 & 0,552 \\
\hline 2-I am ready to start a viable business. & 1,000 & 0,729 \\
\hline 3-I can control the process of setting up a new company. & 1,000 & 0,784 \\
\hline 4-I know the nuts and bolts needed to create an enterprise. & 1,000 & 0,789 \\
\hline 5-I know how to develop a business project. & 1,000 & 0,806 \\
\hline 6-If I tried to create a company, I would have a high probability of success. & 1,000 & 0,655 \\
\hline 7-I am willing to do whatever it takes to be an entrepreneur. & 1,000 & 0,751 \\
\hline 8-My professional goal is to become an entrepreneur. & 1,000 & 0,842 \\
\hline 9-I will make every effort to create and maintain my own company. & 1,000 & 0,833 \\
\hline 10-I am determined to create a company in the future. & 1,000 & 0,888 \\
\hline 11-I have been thinking very seriously about creating a company. & 1,000 & 0,85 \\
\hline 12-I have the firm intention of creating a company within a short time. & 1,000 & 0,804 \\
\hline 13-I doubt my ability to get around the tricky situations and solve the problems by myself (a). & 1,000 & 0,521 \\
\hline 15-I am always able to adapt to different situations. & 1,000 & 0,705 \\
\hline 16-Thanks to your skills and abilities, you know that can handle unforeseen situations. & 1,000 & 0,689 \\
\hline 18-When confronted with a problem, you can usually find several solutions. & 1,000 & 0,736 \\
\hline 19-I always tend to guide my actions by the results obtained in the past. & 1,000 & 0,693 \\
\hline 20-Normally, I can handle anything I encounter on the way. & 1,000 & 0,705 \\
\hline 22-I know myself and I know what makes me feel good. & 1,000 & 0,693 \\
\hline 23-Rarely I can change people's opinion about certain subjects, even if I try that. & 1,000 & 0,747 \\
\hline 24-I know I am able to use my abilities to accomplish a task successfully. & 1,000 & 0,699 \\
\hline 25-I like challenges that have some risk associated with. & 1,000 & 0,562 \\
\hline 26-I put as much effort into what I do when I know that the results will leave me satisfied. & 1,000 & 0,696 \\
\hline 28-Usually I take a shift as something positive. & 1,000 & 0,578 \\
\hline
\end{tabular}

Source: authors' developments.

Table 2

Total Variation Explained

\begin{tabular}{|c|c|c|c|c|c|c|c|c|c|}
\hline \multirow{2}{*}{$\begin{array}{c}\text { Compo- } \\
\text { nent }\end{array}$} & \multicolumn{3}{|c|}{ Initial Eigenvalues } & \multicolumn{3}{c|}{$\begin{array}{c}\text { Extraction Sums of Squared } \\
\text { Loadings }\end{array}$} & \multicolumn{3}{c|}{$\begin{array}{c}\text { Rotation Sums of Squared } \\
\text { Loadings }\end{array}$} \\
\cline { 2 - 11 } & Total & $\begin{array}{c}\text { \% of } \\
\text { Variance }\end{array}$ & $\begin{array}{c}\text { Cumulative } \\
\text { \% }\end{array}$ & Total & $\begin{array}{c}\text { \% of } \\
\text { Variance }\end{array}$ & $\begin{array}{c}\text { Cumulative } \\
\%\end{array}$ & Total & $\begin{array}{c}\text { \% of } \\
\text { Variance }\end{array}$ & $\begin{array}{c}\text { Cumulative } \\
\%\end{array}$ \\
\hline 1 & 10,185 & 42,438 & 42,438 & 10,185 & 42,438 & 42,438 & 5,628 & 23,452 & 23,452 \\
\hline 2 & 3,087 & 12,863 & 55,301 & 3,087 & 12,863 & 55,301 & 4,06 & 16,917 & 40,368 \\
\hline 3 & 1,704 & 7,101 & 62,401 & 1,704 & 7,101 & 62,401 & 4,005 & 16,688 & 57,056 \\
\hline 4 & 1,313 & 5,471 & 67,873 & 1,313 & 5,471 & 67,873 & 2,168 & 9,035 & 66,092 \\
\hline 5 & 1,015 & 4,230 & 72,103 & 1,015 & 4,230 & 72,103 & 1,443 & 6,011 & 72,103 \\
\hline 6 & 0,825 & 3,436 & 75,539 & & & & & & \\
\hline
\end{tabular}

Source: authors' developments.

unsatisfactory factor loads, and the results presented Cronbach's Alpha coefficients that ranged from 0.368 (factor 5) to 0.955 (factor 2).

\subsubsection{Entrepreneurship Education}

Regarding Entrepreneurship Education, we intended to characterize the degree of agreement of the respondents in relation to the improvement of entrepreneurial intention, using a range of statements and taking into account both educational and other institutions. Thus, the areas where educational institutions could contribute to improve- ment of the entrepreneurial intention were assessed by the level of agreement with the statements they were related to. According to the degree of agreement (Agree and Totally Agree) these areas are: to provide the awareness of entrepreneurship as a possible alternative choice (70.7 \%); to stimulate students with ideas to start a new business (80 \%); to offer a work project focused on entrepreneurship (73.4 \%); to set up conferences/ workshops on entrepreneurship (74\%); to put students in direct contact with the network necessary to start a new company (82.7\%); to allow 
Table 3

Factor analysis of the Risk Propensity

\begin{tabular}{|c|c|c|c|c|}
\hline & \multicolumn{4}{|c|}{ Component } \\
\hline & 1 & 2 & 3 & 4 \\
\hline A-Difficulty in starting a business: lack of financial support & 0,649 & 0,285 & $-0,02$ & 0,116 \\
\hline$B$-Difficulty in starting a business: the administrative procedure is very complex & 0,778 & 0,173 & 0,169 & $-0,019$ \\
\hline C-Difficulty in starting a business: little information about how to do it & 0,804 & $-0,059$ & 0,211 & $-0,081$ \\
\hline D-Difficulty in starting a business: lack of skills in the area of management & 0,499 & 0,082 & 0,563 & $-0,044$ \\
\hline E-Difficulty in starting a business: lack of innovative ideas & 0,054 & $-0,232$ & 0,709 & 0,192 \\
\hline F-Difficulty in starting a business: lack of institutional support to do so & 0,655 & $-0,074$ & 0,215 & 0,163 \\
\hline G-Difficulty in starting a business: high risk of failure & 0,163 & 0,119 & 0,812 & 0,04 \\
\hline $\begin{array}{l}H \text {-Difficulty in starting a business: the current economic climate is not favourable } \\
\text { for the development of own business }\end{array}$ & 0,318 & 0,325 & 0,55 & $-0,154$ \\
\hline I-Success of a new company: the personality of the manager/entrepreneur & 0,018 & 0,204 & 0,085 & 0,877 \\
\hline$J$-Success of a new company: the quality of the management team & 0,084 & 0,159 & 0,015 & 0,87 \\
\hline K-Success of a new company: existence of financial support & 0,391 & 0,604 & 0,035 & 0,278 \\
\hline$L$-Success of a new company: the economic context & 0,161 & 0,813 & 0,186 & 0,121 \\
\hline M-Success of a new company: the political context & 0,082 & 0,839 & $-0,04$ & 0,022 \\
\hline$N$-Success of a new company: external partnerships & $-0,104$ & 0,661 & $-0,03$ & 0,17 \\
\hline
\end{tabular}

Source: authors' developments.

student-run businesses to use university facilities (74.6\%); to put entrepreneurial students in touch with each other (81.3\%). Although $34 \%$ of the respondents agreed that promotion by educational institutions of students' financial means to start a business would be a way to improve their interest in entrepreneurship, $32.7 \%$ neither agreed nor disagreed. The same happened with the statement «My interest in entrepreneurship would be improved if the educational institutions offer a bachelor's degree or master's degree in entrepreneurship», with which $32.7 \%$ agreed, but $28.7 \%$ disagreed.

\subsubsection{Family Background}

Regarding the family background, it was observed that half of the interviewees stated that they have a close relative (parents, siblings, uncles, grandparents) who is an entrepreneur, which corresponds to a percentage of $50.7 \%$; the remaining $49.3 \%$ said they did not have such relatives.

\subsubsection{Prior Professional Experience/Training}

We assessed prior Professional Experience/ Training, taking into account whether the interviewee has any experience or not, whether he has already completed an internship or has already worked or is working part-time, full-time for less than one year, full-time for over a year or another situation. The results of this variable showed that about two-thirds of the sample, namely, $66.7 \%$ have a full-time job for more than a year, $12 \%$ had experience as research fellows and $6 \%$ as trainees. Thus, we may conclude that most of the respondents already have some professional experience.

\subsubsection{Risk Propensity}

The results of the factor analysis of Risk Propensity with Varimax rotation showed good results, both with the KMO (0.770) and Bartlett's test $\left(X_{2}(91)=699,611 ; p<0.001\right)$. According to Table 3 , the commonalities ranged from 0.478 (Success of a new company: External partnerships) to 0.819 (Success of a new company: The manager/entrepreneur's personality), represented by letters $(N)$ and (I) respectively.

According to the results presented in table 4, the 4 factors solution (with values greater than 1) explains $63.75 \%$ of the variability in the original variables. These factors were formed from the original variables presented in Table 3: factor 1 (clerical support), factor 2 (macroeconomic environment), factor 3 (entrepreneurial motivation) and factor 4 (management team). The total scale of the variables presented a good internal consistency, demonstrated by (Cronbach Alpha = 0.800 ). The Risk Propensity scale presented values for each value between 0.685 (factor 3) and 0.804 (factor 4).

\subsection{Regression Analysis}

Considering the assessment of the hypothesis, in this study we used the multiple regression analysis in order to verify the existence of a functional relation between the dependent variable and one or more independent variables. Thus, we intended to analyse predictive factors of Entrepreneurial Intention, considering Entrepreneurship Education, Family Background, Prior Professional Experience/Training and Risk Propensity. Table 5 demonstrates that in the fi- 
Total Variation Explained

\begin{tabular}{|c|c|c|c|c|c|c|c|c|c|}
\hline \multirow{2}{*}{ Component } & \multicolumn{3}{|c|}{ Initial Eigenvalues } & \multicolumn{3}{c|}{$\begin{array}{c}\text { Extraction Sums of Squared } \\
\text { Loadings }\end{array}$} & \multicolumn{3}{c|}{$\begin{array}{c}\text { Rotation Sums of Squared } \\
\text { Loadings }\end{array}$} \\
\cline { 2 - 10 } & Total & $\begin{array}{c}\text { \% of } \\
\text { Variance }\end{array}$ & $\begin{array}{c}\text { Cumulative } \\
\text { \% }\end{array}$ & Total & $\begin{array}{c}\text { \% of } \\
\text { Variance }\end{array}$ & $\begin{array}{c}\text { Cumulative } \\
\%\end{array}$ & Total & $\begin{array}{c}\text { \% of } \\
\text { Variance }\end{array}$ & $\begin{array}{c}\text { Cumulative } \\
\%\end{array}$ \\
\hline 1 & 4,083 & 29,165 & 29,165 & 4,083 & 29,165 & 29,165 & 2,686 & 19,185 & 19,185 \\
\hline 2 & 2,324 & 16,597 & 45,762 & 2,324 & 16,597 & 45,762 & 2,534 & 18,1 & 37,284 \\
\hline 3 & 1,429 & 10,209 & 55,971 & 1,429 & 10,209 & 55,971 & 1,946 & 13,901 & 51,185 \\
\hline 4 & 1,089 & 7,777 & 63,748 & 1,089 & 7,777 & 63,748 & 1,759 & 12,563 & 63,748 \\
\hline 5 & 0,87 & 6,214 & 69,962 & & & & & & \\
\hline
\end{tabular}

Source: authors' developments.

nal model Risk Propensity and Entrepreneurship Education are predictors of the EI. Thus, for each unit of increase in Risk Propensity, it is expected that the EI will decrease by 0.25 units. For each unit of increase in Entrepreneurship Education, the EI will increase by 0.366 units. In addition, even though Risk Propensity does not constitute a predictor of the EI by itself (as displayed in model 1), its effect is mediated by the variable Entrepreneurship Education, with which it has a correlation $(r=0.322, p=0.000)$.

In order to complete the data analysis and discussion of the results, the test of hypotheses is presented below.

H1: Entrepreneurship Education positively influences the EI of the Project Apreender 3.0 trainees. Analysis of multiple linear regressions confirmed that Entrepreneurship Education has a pos- itive relation with the EI, since each increased unit in Entrepreneurship Education increases the EI by 0,336 units. These results confirm Hypothesis 1 , as demonstrated by the majority of studies mentioned in the literature review $[12,58,59,60,61,62]$.

H2: Family background positively influences the entrepreneurial intention of the trainees in the project Apreender 3.0. According to the regression analysis in Table 5 , the results referring to the Family Background variable were not satisfactory, showing a non-standardized coefficient of 0.063 . In the available academic literature, there are controversies regarding family's influence on the EI , as some authors believe that Family is a determinant factor that directly influences children's EI $[33,34]$. In the present research, more than half of the respondents answered that they have a close relative (parents, siblings, uncles, grandparents)

Table 5

Coefficients of the variables

\begin{tabular}{|c|c|c|c|c|c|c|c|c|}
\hline & \multirow{2}{*}{ Model } & \multicolumn{2}{|c|}{$\begin{array}{l}\text { Unstandardized } \\
\text { Coefficients }\end{array}$} & \multicolumn{2}{|c|}{$\begin{array}{l}\text { Standardized } \\
\text { Coefficients }\end{array}$} & \multirow{2}{*}{ Sig. } & \multicolumn{2}{|c|}{ Collinearity Statistics } \\
\hline & & B & Std. Error & Beta & $t$ & & Tolerance & VIF \\
\hline \multirow{2}{*}{1} & (Constant) & 3,851 & 0,309 & & 12,456 & 0 & & \\
\hline & Risk propensity & $-0,109$ & 0,088 & $-0,102$ & $-1,242$ & 0,216 & 1 & 1 \\
\hline \multirow{3}{*}{2} & (Constant) & 3,016 & 0,322 & & 9,361 & 0 & & \\
\hline & Risk propensity & $-0,257$ & 0,085 & $-0,239$ & $-3,021$ & 0,003 & 0,898 & 1,114 \\
\hline & Teaching of entrepreneurship & 0,337 & 0,062 & 0,429 & 5,433 & 0 & 0,898 & 1,114 \\
\hline \multirow{4}{*}{3} & (Constant) & 3,011 & 0,323 & & 9,328 & 0 & & \\
\hline & Risk propensity & $-0,259$ & 0,085 & $-0,24$ & $-3,037$ & 0,003 & 0,897 & 1,115 \\
\hline & Teaching of entrepreneurship & 0,337 & 0,062 & 0,43 & 5,438 & 0 & 0,898 & 1,114 \\
\hline & $\begin{array}{l}\text { Has experience as a business owner } \\
\text { or entrepreneur }\end{array}$ & 0,146 & 0,199 & 0,055 & 0,734 & 0,464 & 0,999 & 1,001 \\
\hline \multirow{5}{*}{4} & (Constant) & 2,953 & 0,334 & & 8,854 & 0 & & \\
\hline & Risk propensity & $-0,25$ & 0,086 & $-0,233$ & $-2,903$ & 0,004 & 0,879 & 1,137 \\
\hline & Teaching of entrepreneurship & 0,336 & 0,062 & 0,429 & 5,411 & 0 & 0,897 & 1,115 \\
\hline & $\begin{array}{l}\text { Has experience as a business owner } \\
\text { or entrepreneur }\end{array}$ & 0,146 & 0,199 & 0,055 & 0,732 & 0,465 & 0,999 & 1,001 \\
\hline & $\begin{array}{l}\text { Do you have a close relative } \\
\text { (parents, siblings, uncles, } \\
\text { grandparents) to be a manager? }\end{array}$ & 0,063 & 0,09 & 0,053 & 0,701 & 0,485 & 0,98 & 1,021 \\
\hline
\end{tabular}

Source: authors' developments. 
who is an entrepreneur. However, even this entrepreneurial family background does not mean it can influence one's entrepreneurial intention.

H3: An individual's prior Professional Experience/ Training positively influences the entrepreneurial intention of the trainees in the project Apreender 3.0. The analysis for prior Professional Experience/ Training did not demonstrate a good correlation with the EI, showing a non-standardized coefficient of 0.146 . This result does not allow us to confirm Hypothesis 3, as this study lacks evidence of a significant influence on the EI. In the presented literature review, the majority of authors believe that entrepreneurship training, entrepreneurial experience is one of the driving forces that influence the EI $[42,43,44]$.

H4: The propensity to take risks positively influences the entrepreneurial intention of the trainees in the project Apreender 3.0. The regression analysis for Risk Propensity revealed that it is directly related to the EI. Thus, for each unit of increase in Risk Propensity, it is expected that the EI will decrease by 0.25 units. This fact means that the more the risk increases, the more the entrepreneurial intention decreases. These results allowed us to confirm Hypothesis 4 (The propensity to take risks positively influences the entrepreneurial intention of the trainees in the project Apreender 3.0.), thus confirming the works mentioned in the literature review $[42,63,64,65,66]$.

\section{Conclusion}

The study aimed to identify and analyse the entrepreneurial intention of the trainees in the central region (Coimbra, Lisbon, Covilhã, Aveiro, Figueira da Foz, Castelo Branco, Viseu, Porto, Guarda, Santarém, Abrantes and Vila Real) who in 2017/18, participated in the training sessions of the project Apreender 3.0. To that end, we examined some determinant factors, focusing on independent variables Entrepreneurship Education, Family Background, prior Professional Experience/Training and the Risk Propensity, and their influences on the dependent variable that is the Entrepreneurial Intention.

We chose the research topic due to the pertinence of the study of entrepreneurship and other mentioned factors. Moreover, in our paper, we have justified the findings of various studies on the importance of this particular topic that contributes to the development of the national and regional economies. The results of the analysis of Entrepreneurship Education and entrepreneurship have confirmed that entrepreneurship education significantly influences the entrepreneurial intention of the trainees of the project Apreender 3.0 of the central region.

The analysis of relations between the family background and the entrepreneurial intention demonstrated that there was no positive connection between the two variables. The level of significance was relatively low. Additionally, the literature review presented the division of opinions regarding the role of family background.

Taking into account the obtained results, there is no evidence that the previous experience/training positively influences entrepreneurship, since most of the respondents have been employed for more than 1 year. The findings show there are other aspects that can underlie this result, namely, the fear of creating one's own business and the preference to work under the direction of others, thus avoiding taking risks.

Analysis of the relations between the risk propensity and the entrepreneurial intention confirm that the risk propensity exerts a significant influence on the entrepreneurial intention of the trainees of the project Apreender 3.0. The variable has a relevant weight in the generation of entrepreneurial intention. This conclusion is supported by the majority of the authors presented in the literature review.

Given the above, we elaborated the research hypotheses that were tested and assessed in the data analysis. Two hypotheses ( $\mathrm{H} 1$ and $\mathrm{H} 4)$ have been proven: Entrepreneurship Education and Risk Propensity, respectively. Therefore, both of them influence the entrepreneurial intention; Risk Propensity associated with Entrepreneurship Education presented significant values. The hypotheses (H2 and H3) have not been proven, meaning that Family Background and prior Professional Experience/Training do not significantly the entrepreneurial intention.

The literature review on the determinants of entrepreneurial intention showed that in the academic literature, there are controversies in several aspects regarding the factors analysed in this study. Additionally, the research results may depend on the considered target group, which may dictate whether the results are positive or not. However, these factors must be explored in order to stimulate entrepreneurial intention. Entrepreneurship education should focus on previous experiences/ backgrounds and family background as these turned out to be two surprising factors.

Countries should continue to invest in entrepreneurship support programs. For this purpose, it is crucial for all institutions to work together for developing people's entrepreneurial skills, creating an entrepreneurial and proactive 
spirit. Educational institutions, as well as others, should continue to focus heavily on the promotion of entrepreneurship education as a way to encourage development of new skills and creation of new businesses. This fact has been proven in our research by demonstrating the importance of the training provided by the project Apreender 3.0.

As future lines of research, it is recommended to continue the present study in order to exam- ine other variables that may contribute to the understanding of issues related to entrepreneurship. Further research, focused to other projects and programs, would help to promote and stimulate entrepreneurship. Development of a more specific research would also be useful for perceiving the weak relations between certain determining factors and the entrepreneurial intention.

\section{Acknowledgements}

The article has been prepared with the support of NECE-UBI and National Funds provided by FCT - Foundation for Science and Technology through the project UID/GES/04630/2013.

\section{References}

1. Mitra, J. (2008). Towards an Analytical Framework for Policy Development. In: J. Potter (Ed.), Entrepreneurship and Higher Education (pp. 17-44). OECD Publishing. DOI: 10.1787/9789264044098.

2. Manimala, M. \& Mitra, J. (2008). Higher Education's Role in Entrepreneurship and Economic Development. In: J. Potter (Ed.), Entrepreneurship and Higher Education (pp. 45-64). OECD Publishing. DOI: 10.1787/9789264044104-en (Date of access: 15.10.2019).

3. Lakéus, M. \& Middleton, K. (2015). Venture creation programs: bridging entrepreneurship education and technology transfer. Education + Training, 57(1), 48-73. DOI: https://doi.org/10.1108/ET-02-2013-0013.

4. Amabile, T. \& Kramer, S. (2011). The progress principle: Using small wins to ignite joy, engagement, and creativity at work. Harvard Business Press, 270.

5. Rae, D. (2010). Universities and enterprise education: responding to the challenges of the new era. Journal of Business and Enterprise Development, 17(4), 591-606. DOI: 10.1108/14626001011088741.

6. Comissão Europeia. (2012). Entrepreneurship Education at School in Europe. National Strategies, Curricula and Learning Outcomes. EACEA: Bruxelas. ISBN-978-9-2920-1252

7. Klapper, L., Laeven, L. \& Rajan, R. (2006). Entry regulation as a barrier to entrepreneurship. Financial Economics, 82(3), 591-629. DOI: https://doi.org/10.1016/j.jfineco.2005.09.006 (Date of access: 25.09.2019).

8. Minniti, M. \& Levesque, M. (2008). Recent developments in the economics of entrepreneurship. Journal of Business Venturing, 23(6), 603-612. DOI: https://doi.org/10.1016/j.jbusvent.2008.01.001 (Date of access: 25.09.2019).

9. Rodrigues, R. G., Raposo, M. F. \& Paço, A. M. (2010). Entrepreneurship education and the propensity for business creation: testing a structural model. International Journal of Entrepreneurship and Small Business, 9(1), 58-73. DOI: 10.1504/ IJESB.2010.029506 (Date of access: 26.09.2019).

10. Sánchez, J. (2011). University training for entrepreneurial competencies: Its impact on intention of venture creation. Internacional Entrepreneurship Management Journal, 7(2), 239-254. DOI: https://doi.org/10.1007/s11365-010-0156-x

11. Amorós, J. \& Bosma, N. (2013). Global Entrepreneurship Monitor: Global Report.

12. Audretsch, D., Grilo, I. \& Thurik, A. (2007). Handbook of research on entrepreneurship policy. Cheltenham, UK: Edward Elgar. Entrepreneurship Research Association. Retrieved from: https://www.gemconsortium.org/report (Date of access: 25.09.2019).

13. Liñán, F., Chen, Y. W. (2009). Development and Cross Cultural application of a specific instrument to measure entrepreneurial intentions. Entrepreneurship Theory and Practice, 33(3), 593-617. DOI: https://doi.org/10.1111/j.15406520.2009.00318.x.

14. Pandit, D., Joshi, M. P. \& Tiwari, S. R. (2018). Examining Entrepreneurial Intention in Higher Education: Na Exploratory Study of College Students in India. The Journal of Entrepreneurship, 27(1), 25-46. DOI: 10.1177/0971355717738595.

15. Francis, D. \& Banning, K. (2001). Who wants to be an entrepreneur? Journal of Academy of Business Education, 1(2), $5-11$.

16. Schmitt-Rodermund, E. \& Vondracek, F. (2002). Occupational dreams, choices and aspirations: Adolescents'entrepreneurial prospects and orientations. Journal of Adolescence, 25(1), 65-78. DOI: https://doi.org/10.1006/ jado.2001.0449.

17. Korunka, C., Frank, H., Lueger, M. \& Mugler, J. (2003). The entrepreneurial personality in the context of resources, environment, and the startup process-A configurational approach. Entrepreneurship Theory and Practice, 28(1), 23-42. DOI: https://doi.org/10.1111/1540-8520.00030.

18. Singh, G. \& Denoble, A. (2003). Views on self-employment and personality: An exploratory study. Journal of Development Entrepreneurship, 8(3), 265-281. Retrieved from: https://search.proquest.com/openview/ ad14f323f94be5991e847e6a30d922e9/1?pq-origsite=gscholar\&cbl=32118 (Date of access: 25.09 .2019 ).

19. Crant, J. (1996). The proactive personality scale as a predictor of entrepreneurial intentions. Journal of Small Business Management, 34(3), 42-49. Retrieved from: https://search.proquest.com/openview/e4fcfd6010ed36a2e0f52433cea86735/1?pq-origsite-gscholar\&cbl=49244 (Date of access: 25.09 .2019 ). 
20. Kolvereid, L. (2016). Preference for self-employment prediction of business stat-up intentions and efforts. The International Journal of Entrepreneurship and Innovation, 17(2), 100-109. DOI: https://doi.org/10.1177/1465750316648576

21. Schlaegel, C. \& Koenig, M. (2014). Determinants of entrepreneurial intention: A meta analytic test and integration of competing models. Entrepreneurship Theory and Practice, 38(2), 291-332.

22. Shapero, A. \& Sokol, L. (1982). The Social Dimensions of Entrepreneurship. In: Encyclopedia of Entrepreneurship (pp. 72-90). Englewood Cliffs, NJ: Prentice-Hall Inc. (Date of access: 26.09.2019).

23. Ajzen, I. (1991). The theory of planned behavior. Organizational behavior and human decision processes, 50(2), 179211. DOI: https://doi.org/10.1016/0749-5978(91)90020-T.

24. Feder, E.-S. \& Niţu-Antonie, R.-D. (2017). Connecting gender identity, entrepreneurial training, role models and intentions. International Journal of Gender and Entrepreneurship, 9(1), 87-108. DOI: https://doi.org/10.1108/IJGE-08-20160028 .

25. Brandstatter, H. (2011). Pesrsonality aspects of entrepreneurship: A look at five meta-analyses. Personality and Individual Differences, 51(3), 222-230. DOI: http://dx.doi.org/10.1016/j.paid.2010.007.

26. Ip, C. Y., Wu, S.-C., Liu, H.-C. \& Liang, C. (2018). Social Entrepreneurial Intentions of Students from Hong Kong. The Journal of Entrepreneurship, 27(1), 47-64.

27. Kusmintarti, A., Thoyib, A., Maskie, G. \& Ashar, K. (2016). Entrepreneurial characteristics as a mediation of entrepreneurial education influence on entrepreneurial intention. Journal of Entrepreneurship Education, 19(1), 24-37. Retrieved from: https://search.proquest.com/openview/e6001b0226d433cbeac90d8bfa3eb137/1?pqrigsite=gscholar\&cbl=28224 (Date of access: 26.09.2019).

28. Brito, B. A. (2018). Intenção Empreendedora: Um estudo com Empreendedores e Potenciais Empreendedores do Estado do ACRE [Entrepreneurial Intent: A study with entrepreneurs and potential entrepreneurs of the state of ACRE]. Dissertação apresentada à Universidade Metodista de São Paulo para obtenção de grau de Mestre. São Bernardo do Campo. Retrieved from: http://tede.metodista.br/jspui/handle/tede/1751 (Date of access: 26.09.2019). (In Port).

29. Muller, J., Zapkau, F. \& Schwens, C. (Setember de 2014). Impact of prior entrepreneurial exposure on entrepreneurial intention - Cross cultural evidence. Journal of Enterprising Culture, 22(3), 251-282. DOI: https://doi.org/10.1142/ S0218495814500113.

30. Dutta, D., Li, J. \& Merenda, M. (2011). Fostering entrepreneurship: impact of specialization and diversity in education. International Entrepreneurship and Management Journal, 7, 163-179. DOI: https://doi.org/10.1007/s11365-0100151-2.

31. Vanevenhoven, J. (2013). Advances and Challenges in Entrepreneurship Education. Journal of Small Business Management, 51(3), 446-470. DOI: https://doi.org/10.1111/jsbm.12043.

32. Urban, B. \& Muzamhindo, A. (2018). An Empirical Investigation into Institutions Unlocking Entrepreneurial Activity. The Journal of Entrepreneurship, 27(1), 65-82. DOI: 10.1177/0971355717738597.

33. Matthews, C. \& Moser, S. B. (1996). A longitudinal Investigation of the impact of family background and gender on interest in small firm ownership. Journal of Small Business Management. 34(2), 29-43. Retrieved from: https://search.proquest.com/openview/37d48125c67bbb830c54c75152018e59/1?pq-rigsite=gscholar\&cbl=49244 (Date of access: 26.09.2019).

34. Aldrich, H. E. \& Cliff, J. E. (2003). The pervasive effects of family on entrepreneurship: Towards a family embeddedness perspective. Journal of Business Venturing, 18(5), 573-596. DOI: https://doi.org/10.1016/S0883-9026(03)00011-9.

35. Carr, J. C. \& Sequeira, J. M. (2007). Prior family business exposure as intergenerational influence and entrepreneurial intention: a theory of planned behavior approach. Journal of Business Research, 60(10), 1090-1080. DOI: https://doi. org/10.1016/j.jbusres.2006.12.016.

36. Krueger, N., Reilly, M. \& Carsrud, A. (2000). Competing models of entrepreneurial intentions. Journal of Business Venturing, 15(5-6), 411-432. DOI: https://doi.org/10.1016/S0883-9026(98)00033-0.

37. Peng, Z., Lu, G. \& Kang, H. (2012). Entrepreneurial Intentions and Its Influencing Factors: A Survey of the University Students in Xi'an China. Creative Education, 3, 95-100. DOI: 10.4236/ce.2012.38b021.

38. Santos, R. F. (2016). Determinantes da Intenção Empreendedora no Ensino Superior Português da Região Centro [Determinants of Entrepreneurial Intention in Portuguese Higher Education in the Central Region]. Dissertação em Empreendedorismo e Criação de Empresas, Faculdade de CSH da Universidade da Beira Anterior. Covilhã. Retrieved from: https://ubibliorum.ubi.pt/handle/10400.6/5832 (Date of access: 29.09.2019). (In Port.)

39. Laspita, S., Breugst, N., Heblich, S. \& Patzelt, H. (2012). Intergenerational transmission of entrepreneurial intentions. Journal of Business Venturing, 27(4), 414-435. DOI: https://doi.org/10.1016/j.jbusvent.2011.11.006.

40. Vieira, D. \& Rodrigues, C. (2014). Os estudantes de engenharia e as suas intenções empreendedoras [Engineering students and their entrepreneurial intentions]. Revista Produção Online, 14(1), 242-263. DOI: https://doi.org/10.14488/16761901.v14.i1.1588. (In Port.)

41. Global Entrepreneuship Monitor. (2012). GEM Portugal - Estudo sobre o Empreendedorismo. Instituto Universitário de Lisboa e Sociedade Portuguesa de Inovação. Retrieved from: https://repositorio.iscte-iul.pt > bitstream > GEM Portugal 2013_Final (Date of access: 27.09.2019).

42. Jorge, F. M. (2016). Antecedentes da Intenção Empreendedora: Aplicação a estudantes de uma instituição de ensino superior de Portugal [Background of the Entrepreneurial Intention: Application to students of a higher education institution in Portugal]. Dissertação de Mestrado em ciências económicas e empresarias, apresentdo à Universidade de Trás-os-Montes e Alto Douro. Portugal. (In Port). 
43. Zahra, S. A. (2011). Entrepreneurial capability: Opportunity pursuit and game changing. In: Innovation, strategy, and structure - Organizations, institutions, systems and regions at Copenhagen. Business School, Denmark, June 15-17. Retrieved from: https://conference.druid.dk/acc_papers/lycvus6lgjb22ugojcot9ji3yrte.pdf. (Date of access: 27.09.2019).

44. Olugbola, S. A. (2017). Exploring entrepreneurial readiness of youth and startup success components: Entrepreneurship training. Malaysia Journal of Innovation and Knowledge, 2(3), 155-171. DOI: https://doi.org/10.1016/j.jik.2016.12.004.

45. Fayolle, A. \& Gailly, B. (2015). The impact of entrepreneurship education on entrepreneurial attitudes and intention: Hysteresis and persistence. Journal of Small Business Management, 53(1), 75-93. DOI: https://doi.org/10.1111/jsbm.12065.

46. Delmar, F. \& Davidsson, P. (2000). Where do they come from? Prevalence and characteristics of nascent entrepreneurs. Entrepreneurship and Regional Development, 12(1), 1-23. DOI: https://doi.org/10.1080/089856200283063.

47. Bosma, N., Praag, M. \& Wit, G. (2000). Determinants of Successful Entrepreneurship. Research Institute for Small and Medium. Retrieved from: https://econpapers.repec.org/paper/fthmiklrr/0002_2fe.htm (Date of access: 29.09.2019).

48. Ali, S., Lu, W. \& Wang, W. (2012). Determinants of Entrepreneurial Intentions among the College Students in: China and Pakistan. Journal Of Education and Pracice, 3(11), 13-21.

49. Ellen, A. D. (2010). Entrepreneurial Intentions of Business Students in Finland: Implications for Education. Advances in Management, 3(7), 28-35. Retrieved from: https://econpapers.repec.org/article/mgnjournl/v_3a3_3ay_3a2010_3ai_3a7_ 3aa_3a4.htm (Date of access: 29.09.2019).

50. Mota, M., Sobreira, M. do C., Vale, M., \& Nogueira, L. (2017). Relações de influência de indicadores macroeconômicos na propensão ao risco de empreender [Relationships of influence of macroeconomic indicators on the entrepreneurship risk propensity]. Revista de Gestão, 24(2), 159-169. (Date of access: 27.09.2019). (In Port).

51. Kannadhasan, M., Aramvalarthan, S., \& Pavan Kumar, B. (2014). Relationship among cognitive biases, risk perceptions and individual's decision to start a venture. Decision, 41(1), 87-98. DOI: https://doi.org/10.1007/s40622-014-0029-1.

52. Bandera, C., Collins, R. \& Passerini, K. (2018). Risky business: Experiential learning, information and communications technology, and risk-taking attitudes in entrepreneurship education. The International Journal of Management Education, 16(2), 224-238. DOI: https://doi.org/10.1016/j.ijme.2018.02.006.

53. Baron, R. A. (2006). Opportunity recognition as pattern recognition: how entrepreneurs "connect the dots" to identify new business opportunities. Academy of Management Perspectives, 20(1), 104-119 DOI: https://doi.org/10.5465/ amp.2006.19873412.

54. Minello, I. F., Scherer, L. A. \& Alves, L. C. (2014). Entrepreneurial competencies and business failure. International Journal of Entrepreneurship, 18, 1-15.

55. Block, J., Sander, P. \& Spiegel, F. (2015). How do risk attitudes differ with inthe group of entrepreneurs? The role of motivation and procedural utility. Journal of Small Business Management, 53(1) 183-206. DOI: https://doi.org/10.1111/ jsbm.12060.

56. Laros, J. A. (2012). O uso da análise fatorial: Algumas diretrizes para pesquisadores [The Use of Factor Analysis: Some Guidelines for Researchers]. Retrieved from: https://www.researchgate.net/publication/233735561 (Date of access: 29.09.2019). (In Port.)

57. Marôco, J. (2018). Análise Estatística com SPSS Statistics (7a ed.) [Statistical Analysis with SPSS Statistics. 7th ed.]. Gráfica Manuel Barbosa e Filhos, 1013. (In Port.)

58. Hair, J. F. (2010). Multivariate Data Analysis: A Global Perspective. 7th ed. Upper Saddle River. Prentice Hall.

59. Luthje, C. \& Franke, N. (2003). The "making" of an entrepreneur: testing a model of entrepreneurial intent among engineering students at MIT. $R$ and D Management, 33(2), 135-147. DOI: https://doi.org/10.1111/1467-9310.00288.

60. Honig, B. 2. (2004). Entrepreneurship education: Toward a model of contingency-based business planning. Academy of Management Learning and Education, 3(3), 258-273. DOI: https://doi.org/10.5465/amle.2004.14242112.

61. Kyro, P. C. (2005). Entrepreneurial learning in universities: Bridges across borders. In: P. Kyrö, C. Carrier (Eds.), The dynamics of learning entrepreneurship in a cross-cultural university context (pp. 14-43). University of Tampere.

62. Kuratko, D. F. (2005). Entrepreneurship education: Emerging trends and challenges for the 21st century. White Paper. US Association of Small Business Education, 39. Retrieved from: http://www.unm.edu/ asalazar/Kauffman/Entrep_research/e_ed.pdf (Date of access: 29.09.2019).

63. Naia, A. (2009). Importância da formação inicial no empreendedorismo: estudo do percurso empreendedor de licenciados da FMH [Importance of initial training in entrepreneurship: study of the entrepreneurial path of graduates of FMH]. Dissertação de Mestrado em Ciências da Educação, Faculdade de Psicologia e de Ciências da Educação da Universidade de Lisboa. Retrieved from: https://repositorio.ul.pt/bitstream/10451/848/1/20062_ulfpdep.17823_tm_tese.pdf (Date of access: 27.09.2019). (In Port.)

64. Grabble, J. E. \& Lytton, R. H. (1998). Investor risk tolerance: testing the efficacy of demographics as differentiating and classifying factors. Financial Couseling and Planning, 61-73. Retrieved from: http://hdl.handle.net/10919/30762. (Date of access: 27.09.2019).

65. Miller, D., Kets de Vries, M. F. R., \& Toulouse, J.-M.(1982). Top executive locus ofcontrol and its relationship to strategic-making, structure, and environment. Academy of Management Journal, 25(2), 237-253. DOI: https://doi. org/10.5465/255988.

66. Wang, Y. \& Poutziouris, P. (2010). Entrepreneurial risk taking: empirical evidence from UK family firms. International Journal of Entrepreneurial Behavior \& Research, 16(5), 370-388. DOI: https://doi.org/10.1108/13552551011071841. 
67. Wenhong, F. \& Liuying, Z. (2010). The impact of entrepreneurial thinking system on risk-taking propensity and entrepreneurial behavior. Journal of Chinese Entrepreneurship, 2(2), 165-174. DOI: https://doi.org/10.1108/17561391011051144.

\section{Authors}

Dijinira Ramos - PhD Student in Management, Department of Business and Economics, University of Beira Interior (UBI); ORCID: https://orcid.org/0000-0003-3357-0539 (Covilhã, Portugal; e-mail: ramosdijinira@gmail.com).

Maria José Madeira - PhD in Management, Assistant Professor, Department of Business and Economics, University of Beira Interior (UBI); Research Fellow, NECE - Research Centre in Business Sciences; ORCID: https://orcid.org/00000003-1722-6148 (Covilhã, Portugal; e-mail: maria.jose.madeira@ubi.pt).

Filipe A. P. Duarte - PhD in Management, Assistant Professor, School of Technology and Management in Lamego, Polytechnic Institute of Viseu; Research Fellow, NECE - Research Centre in Business Sciences; Department of Business and Economics, University of Beira Interior (UBI); ORCID: https://orcid.org/ 0000-0001-9381-8562 (Viseu, Portugal; Covilhã, Portugal; e-mail: filipeapduarte@gmail.com). 